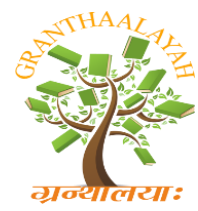

INTERNATIONAL JOURNAL OF RESEARCH GRANTHAALAYAH

A knowledge Repository

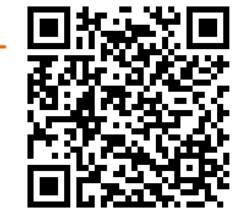

Science

\title{
EXPERT ECONOMIC EVALUATION OF MINERAL RESOURCES IN THE FUNCTION OF ENVIRONMENTAL PROTECTION
}

\author{
Radule Tosovic ${ }^{* 1}$ \\ ${ }^{* 1}$ Department of economic geology, Faculty of Mining and Geology, Belgrade University, \\ SERBIA
}

\begin{abstract}
The successful operation of the mineral sector in modern business conditions, labeled by transition crossing to a market mineral economy and establishing market conditions for the production and trade of mineral raw materials, requires the development of expert economic evaluations of mineral reserves and resources. This evaluation basically represents an expert analysis, which includes four important aspects, namely: geological, mining, economical and environmental. The ecological aspect is related to the previous geoecological analysis of the impact of various phases of the conquest of mineral deposits on the environment, by identifying types of impacts, character of influences, prevention of pollution measures, measures to eliminate the impact and recultivation. Expert economic evaluation is to quantify environmental costs, analyzing their share in the total costs and impact on the economic viability of valorization of mineral raw materials from the mineral deposits.
\end{abstract}

Keywords:

expert economic evaluation, mineral deposit, mineral reserves, geoecology.

Cite This Article: Radule Tosovic, "EXPERT ECONOMIC EVALUATION OF MINERAL RESOURCES IN THE FUNCTION OF ENVIRONMENTAL PROTECTION" International Journal of Research - Granthaalayah, Vol. 4, No. 5 (2016): 106-114.

\section{INTRODUCTION}

The macroeconomic framework of business and economic trends in Serbia in the coming years, which will be reflected in the mineral economy, among other things, is defined by the fiscal strategy for 2015 with projections for 2016 and 2017 year [2]. The general framework and main objectives and guidelines of the economic policies are arising from the strategic orientations of the Government of the Republic of Serbia in the European integration process for faster acquisition of full membership in the EU. The present general framework of economic policy for the aforementioned period, among other things, was established by the development documents of the Government, including the National Programme for the Adoption of the EU Acquis (2013 - 2016), general and sectoral national development strategies. In these economic directions, in particular is highlighted the need for the development of a market economy and strengthening of 
its capacity in order to respond to the upcoming competition and market forces within the EU. These trends and market adaptations of the mineral sector condition the use of European experience and good practice in basic production of mineral resources. The two main objectives of economic policy in the medium term are: (1) The establishment of macroeconomic stability, implementation of fiscal consolidation and strengthening of financial sector stability; and (2) Removal of barriers to economic growth and competitiveness implementing comprehensive structural reforms [2].

The country's mineral economy and mineral sector activities are directly related to mineral policy, which stems from the country's economic policy, and includes a general definition of the relationship to the conditions, manner and use of mineral resources. Therefore, the events in the mining sector are directly connected with the aforementioned economic developments, although mining as a basic material sector has part of autonomy in achievement of material and economic results. For mineral economics, this means the need to implement European practices and experience in the functioning and directing the mineral sector of the country and harmonization of relevant legal and regulatory elements with the European legislation in the field of mining and geology.

Analytically viewed, in the mineral sector in the previous 2014 year was particularly pronounced negative impact of floods, which inflicted the greatest damage to industry, especially in the mining sector on the part with surface coal mining and electricity generation sector. These events, together with decline in production identified yoy decline in total industrial production in 2014 compared to 2013 from $6.3 \%$ in the period January - October $(-14.3 \%$ and $-18.5 \%$, respectively) [2].

The latest data [4] show that industrial production in Serbia in February 2015, is lower 3.3\% than in February 2014, and compared to the average of 2014 decreased by $6.3 \%$. Industrial production in the period between January-February 2015, compared to the same period of 2014, decreased by $3.1 \%$. Observed by sectors in February 2015, compared to the same month of 2014, the mining sector recorded a decline of $13.6 \%$. The biggest influence on the decline in production in this sector had a drop [1]: exploitation of coal (18.2\%), exploitation of crude oil and natural gas $(6.2 \%)$, exploitation of metal ores $(3.9 \%)$ and other mining which includes the exploitation of non-metallic minerals (10.3\%).

To illustrate the complexity of the macroeconomic conditions of functioning in the mineral economy of Serbia may serve an example of PIS in the first quarter of 2015. The first three months were marked by a very low price of crude oil on the world market (below $50 \$ / \mathrm{bbl}$ ) and the strengthening of the dollar, causing foreign exchange losses were almost 10 times higher than in the same period in last year [3]. Despite the difficult economic situation, the PIS has managed to increase its total turnover of petroleum products by $6 \%$, while the share of the retail market in Serbia increased by $2 \%$ compared with the first quarter last year. Adverse macroeconomic trends are reflected in the EBITDA, which in the first quarter of 2015 amounted to 7.2 billion dinars, which is 53 percent less than the same period last year, while in the first quarter of 2015 recorded a net loss of 4.7 billion dinars [3]. 
These data illustrate the necessity of economic monitoring state of reserves of metallic, nonmetallic and energy minerals and actualization of their cost-effectiveness, efficiency and profitability. The simplest and most effective way of present economic monitoring is expert economic evaluation. Preparation of strategic long-term decisions about the production of mineral raw materials for various economic sectors requires actualization of state reserves of metallic, non-metallic and energy minerals. It can be achieved through the creation of special economic expert evaluation, which contains the necessary elements of geological and economic evaluation, with the participation of all relevant factors and the same indicators [10].

Application of expert economic evaluation is relatively uncommon in domestic practice, and is based on the basic assumptions of mineral economics, basic principles and issues related to evaluation of mineral resources and connections with geo-ecological aspects of the evaluation [516]. It is important due to the modern approach, evaluation reliability and application effects of the current conditions of the expert work in the mineral sector, particularly in order to prepare and make important strategic decisions in the mineral economy of Serbia, which particularly include an ecological component. The main objective of this paper is a general review of the place, the significance and role of the expert economic evaluation in modern business conditions as a basis for strategic decision-making in the mining sector, particularly with the inclusion of ecology, then the inclusion of the concept of sustainable development and the successful development of mineral economics.

\section{EXPERT ECONOMIC EVALUATION OF MINERAL RESOURCES}

Expert economic evaluation, in its broadest sense, is a form of geological and economic evaluation of mineral resources. The other known forms of evaluation are: geological, economic (value), technical and exploitation, technological and other evaluation. Each of them has a specific function, tasks, methods and precise objective of economic analysis and economic evaluation.

Expert economic evaluation has developed structure, consisting of the appropriate factors (metallogenic, geological, legislative and legal, technical and exploitation, technological, regional, market, social-political-economic and geo-ecological), as well as natural, value and synthetic indicators [10]. The expert economic evaluation can be extracted in 4 important aspects, namely: geological, mining, economically and environmentally. The first two are basic, the third roof, and the fourth is in parallel with the three previous.

Expert economic evaluation is essentially a complex methodological procedure, with the primary objective of determining the economic significance of the object under evaluation, where they performed geological exploration of different phases and stages. This evaluation may include: (a) mineral-raw material base of a certain area; and (b) Individual geological and economic objectives. 


\subsection{EXPERT ECONOMIC EVALUATION OF THE MINERAL-RAW MATERIAL BASE OF A CERTAIN AREA}

Expert economic evaluation of the mineral-raw material base of a certain area may be related to the area of: (a) the countries as a whole; (b) regions; (c) county; (d) municipalities; and (e) other territorial units. This evaluation should be worked by experts of highly educated scientific and professional teams, made up of a large number of engineers of geology and mining, economists, technologists and experts of other significant profile. Expert economic evaluation in fact refers to the re-evaluation of known mineral reserves and resources, with the actualized condition of factors and evaluation indicators. This evaluation should include explored and potential metallic, non-metallic and energy mineral reserves and resources of subject areas. For the purposes of strategic, economic and business planning is necessary evaluation work in the area of the country as a whole.

A characteristic example of the use of innovated expert geological and economic evaluation of mineral resources is an example of the Russian Federation, which carried out this evaluation in 1995 [8]. In this revision the evaluation were involved 145 experts-professionals, who have geologically and economically analyzed 35 types of mineral resources in over 2,600 facilities. At each of these facilities, there was made division of reserves on active and passive. Active reserves belong to the reserves of deposits, whose utilization is possible with the acceptable costeffectiveness in the current economic conditions. The main characteristic of the active reserves is the equalization or enlarging the medium content of useful components in relation to the minimum economic content, calculated taking into account the current level of exploitation costs and the market price of the product, as well as existing legal obligations in terms of fees, taxes, contributions, write-offs, etc. Thus, this content in market conditions should be such that at least a usable value of mineral raw materials (useful components) provides covering of operating costs, the settlement of the corresponding taxes and other various contributions and write-offs, while ensuring a minimum income, which corresponds to the rate of interest of the banks with inflation coverage. In order to win the so-called Reserve deposits must be used the indicators of effectiveness with the inclusion of taxes, contributions and appropriate deductions. These indicators include: the discounted net profit, index of income (profitability), internal rate of profit, profitability in relation to production funds, profitability according to the of operating costs and capital investment payback time.

The aforementioned methodology of expert economic evaluation, essentially a revision or reevaluation of reserves of mineral raw materials, being implemented in Russia, can be successfully applied in domestic conditions, because it is based on commonly acceptable principles and criteria of the modern market mineral economics, management of mineral resources and economic evaluation.

From the geological aspect and the aspect of management of mineral resources is necessary to carry out the on-going and modern evaluation of known explored deposits of raw materials in Serbia, whose justification is confirmed by the fact that the latest economic evaluation of the mineral wealth of the country was made in 1971 with the balance of reserves on 31.12.1969. [8]. New economic evaluation means the need that the found and explored deposits and reserves must be evaluated not only through the natural indicators, but particularly complemented by the 
use of modern methods of market and economic evaluation, as well as the inclusion of appropriate environmental costs.

\subsection{EXPERT ECONOMIC EVALUATION OF CERTAIN GEOLOGICAL-ECONOMIC OBJECTIVES}

Expert economic and geological-economic evaluation may include the following individual geological-economic objectives $[11,12]$ :

(a) The new economic objectives;

(b) The old economic objectives; and

(c) The technogenic economic objectives.

The new economic objectives include: concept, deposits or anomalies in the various stages/phases of research.

The old economic objectives include: exploited deposits or old mines preserved in the narrow sense of the technological, economic, monopoly, military-strategic and environmental reasons, or off-balance sheet deposits, which are recorded in the existing balance sheet of mineral resources of the state.

Technogenic economic objectives include objectives associated with the waste of mining production, preparation and processing, respectively various landfills, Slag and ash ground, etc.

Expert economic evaluation is based on a complex, analytical and synthetic consideration of previously accumulated designing materials (existing studies, reports, expertises, possible previous expert evaluation, studies on reserves, etc.). Practically, the basis for a concrete expert economic evaluation is consisted of complex and varied data (information) of fundamental geological research and study, then the results of evaluation of potentiality (forecasting), prospecting, research from previous geological-economic analysis or evaluation.

According to current knowledge, the following mineral resources of Serbia and their facilities (anomalies, phenomena, ore bodies, deposits, etc.), deserve priority status of expert evaluations of previously conducted research: (a) metal-resources: copper, lead and zinc, antimony, nickel, chromium, tungsten, gold, etc.; (b) non-metallic resources: graphite, quartz raw materials, magnesite, tee, diatomite, etc.; and (c) energy resources: oil, gas, coal and oil shale. As such, should be the subject of expert economic evaluation, which will be the basis for decision-making on deposits, which will activate the production and perform market valorization.

\section{GEOLOGICAL FACTORS AND EXPERT ECONOMIC EVALUATION}

In terms of implementation of sustainable development strategies in the field of mineral economy of Serbia and geological, mining and technological activities related to mineral resources are of extremely great importance to economic expert evaluation of mineral resources, deposits and occurrences of mineral resources, especially its part, which includes the geoecological issues. 
The main objective of the expert economic evaluation is to determine the necessary parameters for determining the economic importance of mineral resources, deposits or metallogenic units, which will consequently affect the planning and management of geological research, as well as the sustainable use of mineral raw materials fom defined deposits. Expert economic evaluation proceeds on the objective consideration of the nine groups of factors and a large number of indicators derived from them. A special significant place, in the so far development of mineral economics, expansion of the mineral-raw material base and the functioning of the mineral sector in Serbia, by applying the principles of sustainable development, possess a factor analysis of geoecological expert economic evaluation. Geo-ecological analysis and display of geo-ecological problems in this paper, due to the limited space, have a general character, and detailed presentation will take place in continuation of scientific research, applicative and expert work of the author in the upcoming period.

Geo-ecological factors of expert economic evaluation of the mineral resources, as one of the nine groups of factors, include a wide range of different data, which are essential for understanding of geoecological conditions, then the impact and associated consequences of geological-mining technology activities on deposits of mineral raw materials for the living environment, but also and planning and programming elements of necessary measures to reduce, neutralize, eliminate or prevent adverse effects and impacts on the environment and supporting procedures of recultivation and remediation.

Geo-ecological factors in the entire developed form, as a segment of the expert system of integrated economic evaluation of mineral resources, include the following individual factors:

1) Geo-ecological type of minerals, ores or deposits;

2) Condition of geological environment, namely: (a) before the commencement of geological exploration, (b) prior to commencement of exploitation and (c) prior to commencement of mineral raw-materials;

3) Changes of geological environment condition, influenced by (a) geological exploration, (b) exploitation and (c) preparation of mineral raw-materials;

4) The impact of exploration, exploitation, preparation, valorization of mineral resources and associated processes on the changes of condition: (a) air; (b) water; (c) land and (d) flora and fauna;

5) Measures of recultivization and revitalization of the geological environment;

6) The possibility of complex utilization of mineral raw-materials, especially utilization/removal of environmentally important/toxic components;

7) Geo-ecological state of tailings and their impact on the living environment;

8) The using possibility of technogenic mineral raw-materials, existing or arising during the use of deposits;

9) Monitoring of geological environment in the local area and beyond;

10) Geo-ecological conservation of mineral raw-materials;

11) Geo-ethical factors and their impact on the evaluation of the deposits;

12) The impact of the construction of infrastructure facilities on the natural/geological environment;

13) Sustainable use of mineral raw-materials in the deposit;

14) Indicators of sustainable use of mineral raw-materials in the deposit; 
15) Post-exploitation use of open pits and underground mining rooms;

16) Measures to prevent pollution in various procedural-operational phases in: exploration, exploitation, preparation, valorization of mineral resources and associated processes;

17) Environmental costs and their impact on profitability and balance reserves.

The above factors, it is necessary to fully, completely and meticulously studied in a variety of metallic, nonmetallic mineral and energy resources, and their scope and level of treatment depends on the type of mineral resources, the level of their geoecological impact on the environment, the availability of baseline information and detailed knowledge of the genetic, geochemical and geological processes, which are essential for monitoring the process in different media environment.

For a complete economic expert evaluation, as well as recognizing the importance of the geoecological factors, particularly in issues of this study are particularly important relations of geoecological factors with other factors of expert economic evaluation or relations: the geoecological factors - metallogenic factors, the geo-ecological factors - geological factors, the geoecological factors - technical and exploitation factors, the geo-ecological factors - technological factors, geo-ecological factors - legislative and legal factors, the geo-ecological factors - market factors, the geo-ecological factors - regional factors and geo-ecological factors - socio-politicaleconomic-strategic factors.

The problematic relationship of geoecological factors such as a subsystem of expert economic evaluation deposits includes both considered geogenic, and with a certain specificity, technogenic deposits or tailings, slag and ash grounds, as the associating products with the exploration, exploitation, treatment and use of mineral raw-materials.

Correlation of geoecological and other factors within the economic expert evaluation deposit is economically very important, because if the expert economic evaluation shows the inadequacy of environmental exploitation, geological research and the accompanying investments should stop and not start activities leading to the construction of the mine. In accordance with the gradualness of applying expert economic evaluation deposits and appearance of mineral raw materials, there is a necessity of gathering all relevant geo-ecological information from the first phase of the research, in order to complete the processing of such geoecological factors and its detailing on the basis of the displayed factor elements.

Geological and economic evaluation of mineral raw-materials deposits in the last two decades under the influence of methods of modeling and systems analysis, respectively the systems engineering, focuses on the geology and economic modeling, with the systemic structure [10]. Under this approach, the geological-economic evaluation and individual factors can be expressed through appropriate models or sub-models as the constituents of a lower order. In this way, and to display of these individual geoecological factors can be carried out through the model structure, which in this way results in geoecological model. This facilitates a model display of important geoecological characteristics and allows their adequate evaluation and inclusion in the expert economic evaluation. 


\section{CONCLUSION}

The country's mineral economy and mineral sector activities are directly related to mineral policy, which stems from the country's economic policy. Functioning of the mineral sector is directly related to the macroeconomic business trends, but partially has autonomy in exercising material and economic results. Preparation of strategic long-term decisions about the production of mineral raw materials for various economic sectors, with the inclusion of environmental aspects and sustainable development requires actualization of state reserves of mineral raw materials, which is achieved through the creation of expert economic evaluation.

Transitional changes and general orientation towards European integration, which involves the mineral-raw material complex, especially geo-industry and geo-administration, also influence the expert economic expert work and economic evaluation of mineral resources, particularly the need of the current market defining of the key economic characteristics of mineral resources in Serbia. Expert economic evaluation of mineral resources, as the highest hierarchical system, comprises nine subsystems - factors, among which is the geo-ecological factors. They include a wide range of different data, essential for understanding the geoecological conditions, then the impact and consequences of supporting geological-mining-technological activities on mineral raw-materils deposits for the environment, but also the planning and programming elements of necessary measures to reduce, neutralize, eliminate or prevent adverse effects and impacts on the environment and supporting processes of recultivation and remediation.

The discussed the geo-ecological problems, in addition to great importance to the geo-ecological aspects of the expert economic evaluation is important for defining the strategy of sustainable use of mineral resources, as well as practical, rational and effective use of the required investments. In the upcoming time is very important to intensify the systematic and thorough analysis of geoecological factors of expert economic evaluation and the development of geoecological model of mineral deposits in Serbia, due to the proper handling of the geoecological problems of mineral resources. Expert economic evaluation should be an integral part of the strategy of geological exploration of mineral resources in Serbia and in direct function of successful management of mineral resources, sustainable development of the mineral sector and the mineral economy of the country.

\section{REFERENCES}

[1] Indeksi industrijske proizvodnje u Republici Srbiji, februar 2015 - Prethodni rezultati, Republički zavod za statistiku, god. LXV, broj 79, Beograd, 2015, 4 pp.

[2] Fiskalna strategija za 2015. godinu sa projekcijama za 2016. i 2017. godinu, Službeni glasnik RS, br. 15/15, Beograd, 2015.

[3] Fjodorov A., Rezultatati poslovanja NIS-a za prvi kvartal 2015, NIS A.D., Novi sad, 2015. http://www.nis.eu/prescentar/nis-na-beogradskoj-berzi-predstavio-rezultatateposlovanja-za-prvi-kvartal-2015.

[4] Republika Srbija - Industrijska proizvodnja u februaru 2015, Republički zavod za statistiku, Beograd, 2015, 1 pp.

[5] Rudenno V., The Mining Valuation Handbook: Mining and Energy Valuation for Investors and Management, Wrightbooks; 4 edition, 2012, 624 pp. 
[6] Rundge I., Mining Economics and Strategy, Society for Mining Metallurgy \& Exploration, 1 edition, Littleton, Colorado, 1998, 316 pp.

[7] Torries F.T., Evaluating Mineral Projects: Applications and Misconceptions, Society for Mining Metallurgy \& Exploration, Littleton, Colorado, 1998, 172 pp.

[8] Tošović R., Expert Economic Evaluation of Mineral Resources in Modern Conditions of Transition and Management, Proceeding of 14th ICDQM-2011, Belgrade, 2011, 624634.

[9] Tošović R., Management in Modern Conditions of Serbian Mineral Economy, MISKO 10, Belgrade, 2010, 411-434.

[10] Tošović R., Geološko-ekonomsko modeliranje polimetaličnog ležišta Rudnik, Katedra ekonomske geologije RGF-a, Poseb. izd. br. 8, Beograd, 2006, 226 pp.

[11] Tošović R., Razrada kriterijuma savremene geološko-ekonomske ocene resursa i rezervi nemetaličnih mineralnih sirovina Srbije, Beograd, 2010, 135 pp.

[12] Tošović R., Razrada kriterijuma savremene geološko-ekonomske ocene resursa i rezervi metaličnih mineralnih sirovina Srbije, Beograd, 2010, 115 pp.

[13] Tošović R., Geoecological model as a subsystem of the geological-economic model of mineral deposit, Proceedings of the 4th International Symposium Mining and Environmental Protection, Faculty of Mining and Geology, Belgrade, 2003, 27-32.

[14] Tošović R., D. Polomčić, B. Knežević, Mineral resources and local ecological action plan, Proceedings of the 4th International Symposium Mining and Environmental Protection, Faculty of Mining and Geology, Belgrade, 2003, 60-64.

[15] Tošović R., Milovanović D., Relacije geološko-ekonomske ocene ležišta mineralnih sirovina $i$ prifizibiliti $i$ fizibiliti studije pri oceni ineralnih resursa Srbije, Zbornik savetovanja IMES'03, Aranđelovac, 2003, 252-260.

[16] Wellmer F.W., Dalheimer M., Wagner M., Economic Evaluations in Exploration, Springer; 2nd edition, 2010, $264 \mathrm{pp}$. . 